\title{
Partial Equilibrium Analysis to Determine the Impacts of a Southern African Customs Union-European Union Economic Partnership Agreement on Botswana's Imports
}

\author{
${ }^{1}$ Buyani Thomy, ${ }^{2}$ Gurudeo Anand Tularam and ${ }^{3}$ Mahinda Siriwardana \\ ${ }^{1}$ Griffith School of Environment, Griffith University, Australia \\ ${ }^{2}$ Science Environment Engineering and Technology [ENV], \\ Environmental Futures Centre, Griffith University, Brisbane, Australia \\ ${ }^{3}$ School of Business, Economics and Public Policy, \\ Faculty of Professions Armidale, University of New England, Australia
}

Received 2013-06-13, Revised 2013-07-03; Accepted 2013-07-11

\begin{abstract}
Botswana along with its Southern African Customs Union (SACU) states is negotiating a European Union (SACU-EU) Economic Partnership Agreement (EPA). The negotiations are contentious both within SACU and against the EU and not surprisingly, the initial 2007 deadline not met. This study investigates the effects of such an agreement on Botswana's import of food, beverages and tobacco using the Vinerian partial equilibrium method. The authors attempt to quantify the impacts of a reciprocal duty and quota free EPA on Botswana's imports of food, beverages and tobacco under SACU-EU EPA's. The partial equilibrium analysis suggests that a net welfare benefit for the Botswana consumers is possible. Although there are some trade diversion and tariff revenue losses these do not appear to be large enough to negate the effects of the welfare enhancing trade creation.
\end{abstract}

Keywords: Partial Equilibrium, Mathematical Finance, Food Trade, Botswana, SACU, International Trade, EU, Trade Barriers, EPA's

\section{INTRODUCTION}

Botswana is involved in a trade liberation agreement with the European Union (EU). Botswana also belongs to the Southern African Customs Union (SACU) and together with other members is involved in negotiations with the European Union members to liberalise trade between the two groups. If successful, such an arrangement will have significant implications for the domestic economic welfare of both consumers and producers. This study examines the impacts of such anagreement on imports of food, beverages and tobacco in particular into Botswana. Currently Botswana is dependent on the South African (a member of SACU) imports for supplying these goods.
Botswana, Lesotho and Swaziland have initiated the SACU-EU EPA negotiations by signing an interim EPA; but Namibia is rather critical of the impacts while South Africa already has a trade arrangement with the EU Trade, Development and Cooperation Agreement (TDCA). The SACU-EU EPA negotiations are proving contentious and is taking somewhat longer than expected, given the initial deadline was December 2007 (Meyn, 2004b). It is therefore important that studies be conducted to estimate the effects of a SACU-EU EPA on Botswana's welfare. Such studies will provide the Batswana negotiators critical information to make the best possible decision under the conditions. This study seeks to contribute to the literature on trade regime change by investigating the effects of the trade Corresponding Author: Buyani Thomy, Griffith School of Environment, Griffith University, Australia 
liberalization on countries such as Botswana.This study uses the Vinerian partial equilibrium method to quantify possible changes in imports of food, beverages and tobacco based on benefits of importing such commodities under the SACU-EU duty and quota free EPA. The analysis is conducted under the assumption that the economic partnership agreements are implemented at a $100 \%$ tariff rate reductions and are reciprocal; that is, there will be no tariff duties on Botswana's imports from the EU and its exports to the EU. More specifically, this research will simulate the welfare impacts of liberalising trade by examining the impacts of SACU-EU EPA on imports of food, beverages and tobacco to Botswana by estimating: (i) tariff revenue and welfare effects due to: Consumption, trade creation and trade diversion; and (ii) net tariff revenue and welfare effects.

The above information will be used to derive policy implications for the region. The study is organised in the following manner: the next section presents a review of the literature that includes an outline of Botswana's involvement in trade agreements. The model and data analysis is then explained and this is followed by the results and discussion. Finally, the conclusion and limitations section is presented.

\subsection{Literature Review and Background}

Milner et al. (2005) investigated the impact of an African Carribean Pacific-EU EPA on East African Cooperation (EAC)-that is, Kenya, Tanzania and Uganda and concluded that the welfare effects (excluding revenue effects) of the EU agreement will be small. Be it positive or negative there would be short-run adjustment costs mainly in the form of tariff revenue losses. Kenya was the dominant EAC supplier, supplying over $80 \%$ of Tanzania's and Uganda's imports. The EPA's resulted in a rise of $16 \%$ (54.8 billion of Tanzanian Shillings (TZSH)) and $23 \%$ (28.4 billion of Ugandan Shillings). The authors predicted an increase in EU imports because of trade creation, trade diversion and consumption effects due to tariff rates reduction for EU products. Although welfare increased due to trade creation and consumption effects, Milner et al. (2005) noted high negative effects as some of the trade was diverted from efficient non-EU members. Tanzania's overall welfare fell by 9billion TZSH or $0.5 \%$ of GDP. For Uganda, the trade diversion effects were not large enough to offset the benefits of trade creation and consumption effects and the welfare increased by $0.05 \%$ of the Ugandan GDP.
Zgovu and Kweka (2007) used the Milner et al. (2005) model to quantify the effects of full and less-thanfull trade reciprocity under the ACP-EU EPA for Malawi and Tanzania. The study used a six-digit level of Harmonised System (HS) trade data under a partial equilibrium model. There were some welfare enhancingconsumption and trade creation effects but the positives were negated by the welfare-lowering trade diversion and tariff revenue losses. The removal of tariffs on EU imports increased Malawi's imports by 5,962.454 million-Malawian Kwacha (MK). A 65\% rise in 2003 imports of MK9, 239.989 million. Tanzania also had an increase of TZSH275, 990.9 million-79\% increase in 2004 imports of TZSH 349, 46.2 million. Tanzania experienced an overall revenue loss of $52 \%$ or TZSH54, 811.3 million while Malawi had a revenue loss of $24 \%$ or MK 7,766.0 million. Zgovu and Kweka (2007) noted that both countries hadsignificant losses of government tax revenue. The net welfare losses were estimated to be MK792.866 million for Malawi and TZSH29, 003.1 million for Tanzania. This was possibly due to substitution of imports from low cost producing countries, to relatively higher cost producing EU. The trade diversion outweighed both trade creation and consumption welfare effects.

Sigwele (2007) used the Social Accounting Matrices (SAM) model to measure the effects of trade liberalisation, market access on household food security/welfare and the competitiveness of the agricultural sector in Botswana. The author noted that Botswana would benefit from an increased export market access and food security. The study showed Botswana was dependent on foreign producers for basic food goods and needed to improve export market access to generate foreign exchange to purchase those imports. Increases in beef export revenue were found to be beneficial to households and the meat processing industry. Increased textile export income also had similar effects.

Sawkut and Boopen (2010) studied the impact of liberalising trade within the Common Market for Eastern Africa (COMESA). Firstly, they assessed the impact of the common external tariff while leaving internal tariffs within COMES Aunchanged to reflect the real situation; secondly, they simulated the effects of implementing the free trade Agreement (FTA) fully by removing all tariffs within COMESA. Finally, they assessed the impact of a common external tariff in a fully operational COMESA FTA using the Global Trade Analysis Project (GTAP) framework. On a macro level, the real GDP varied inversely with average external tariff changes in each region. But they alsonoted that real GDP for all 
COMESA is likely to increase when the full COMESA FTA is operational. Complete removal of internal tariffs in COMESA would be beneficial for all countries and in particular those countries with higher tariffs, such as SACU countries. Further, changes in taxes were positive on government revenue for the rest of SACU (i.e., all SACU excluding South Africa), Uganda, Zimbabwe and Madagascar, with the rest of SACU experiencing the highest positive change and the rest of SADC category having the highest negative change. Change in total tax revenue collected is largely attributed to changes in import tax revenue and income taxes collected. For SACU, a positive change in income tax revenue of US\$ 12.1 million was the main contributor to the change in the total tax revenue collected (US\$ 20.6 million). The large negative change in tax revenue for the rest of SADC was due to the decrease in income payments of US\$ 62 million and a decrease in imports tax revenue of US\$ 23.2 million (Sawkut and Boopen, 2010).

\subsection{Botswana's Trade Agreements and Related Issues}

Botswana's trade agreements are generally implemented via the Southern Africa Customs Union. The major trading partners are SACU, United Kingdom, United States and the rest of Europe (Akinkugbe et al., 2006). Botswana also Has Double Taxation Avoidance Agreements (DTAA) with: India, Namibia, Zimbabwe, South Africa, United Kingdom, Barbados, France, Mauritius, Seychelles and Sweden. Of all the arrangements that Botswana has, SACU is the most notable in terms of influence and trade value (Akinkugbe et al., 2006). Apart from the SACU membership and the bilateral agreements above, Botswana's trade is facilitated under such agreements as: the SADC trade protocol, the Botswana-Zimbabwe Trade Agreement and the ACP-EU "Cotonou" trade agreements. Since 2001, Botswana also undertakes trade with the United States under the Africa Growth Opportunity Act (AGOA) and there has been an anticipated SACU-USA FTA. Currently, the SACUUSA FTA negotiations have been discontinued (Lehloenya, 2009). Table 1 lists trade agreements of Botswana along with implementation status.

The different political and economic interests of the countries involved in the SACU-EU agreement are proving to be rather challenging. South Africa is interested in fostering the success of its manufacturing industry such as the automobile industry; and to get cheaper agricultural products from competitive producers worldwide. Botswana is interested in securing better arrangements to sell their agricultural and raw materials overseas and also acquiring cheaper automobiles from relatively cheaper countries such as Japan. To be the successful in the establishment of the SACU-EU EPAs it is necessary for SACU states to negotiate as a significant group. SACU states need to find common goals to have a stronger negotiating power. SACU states risk losing the power and ability to help foster their infant industries, which will face higher competition from their EU counterparts. SACU will also experience increased competition for raw materials. Tariff revenue losses are unavoidable and will be significant for some of the countries. For example, $28.2 \%$ of Lesotho's GDP for year 2006 was covered by SACU revenue pool funds (Flatters and Stern, 2005). Contentiously, Meyn (2004a) argued that though EU states that EPA's are development tools for ACP countries, the EU is strategically pursuing its own economic interests.

Table 1. Important trade agreements of Botswana

\begin{tabular}{ll}
\hline Agreement & Status \\
\hline SACU & Agreed framework for revenue sharing and institutional arrangements \\
SADC FTA & Implemented and common external tariff revenue in effect \\
& Being implemented \\
Services negotiations have not started \\
EU-South Africa ETA & Being implemented (affects Botswana through membership of SACU \\
SACU-EU EPA & some countries trading under the interim EPAs \\
& Negotiations still on-going \\
AGOA & Botswana became eligible in 2001 \\
WTO & Uruguay round agreement in effect 1986 to 1994 \\
& Doha round agreements started in 2001 and on-going \\
SACU-USA FTA & Stalled and may not be finalized any time soon \\
Botswana-Zimbabwe trade agreement & In effect \\
\hline
\end{tabular}

Sources: Adapted from Akinkugbe et al. (2006), SACU, SADC and WTO websites 


\section{MATERIALS AND METHODS}

\subsection{Partial Vs. Computable General Equilibrium Model}

The impact of changes in trade policies has been analysed using the Computable General Equilibrium (CGE) setting and/or the partial equilibrium. CGE simulates the simultaneous effects of a trade policy on severalrelated markets or industries. CGE can capture multi-sectoral interactions, multi-country interactions and second-round effects of changes in trade agreementsor trade control. However, CGE has some shortcomings in that sometimes developing African, Caribbean and Pacific (ACP) countries do not have enough data in the databases such as the Global Trade Analysis Project (GTAP). The databases for CGEslack the commodity detail to take into account specific and sensitive products of interest for most developing countries. In such cases CGE modelling is unsuitable. Therefore, use of theless data-intensive Partial Equilibrium (PE) modelling appears appropriate. Similar to CGE's, the PE modelling is versatile enough to capture static effects on import, tariff revenue andwelfare (Zgovu and Kweka, 2007). The PE models assume that all otherindustries except the one in question are unaffected by changes in trade policy. When a PE analysis is undertaken only the concerned market isexamined and effects on subsequent markets are ignored or assumed constant.

ThePE method is chosen for this study because it permits analysis ofa high level of disaggregation in the data (Milner et al., 2005). The method allows analysis of impacts of a tariff change at asector by sector level and also helps isolate the most affected commodities. The PE method is also well suited to indicateshort run effects (specifically costs and benefits) associated with tariff revenuelosses. Importantly, the data collected from Botswana Central Statistics Office (CSO) alsorenders the CGE model inapplicable while PE is applicable. There are some assumptions but they will be investigated using sensitivity analysis described later.

Figure 1 illustrates the impact of a reciprocal SACUEU EPA. In this graph, domestic production capability is ruled out using the assumption of no domestic production. The welfare is defined by reference to consumer surplus with respect to the importdemand function $\left(D_{H}\right)$.
Where:

$\mathrm{D}_{\mathrm{H}} \quad=$ Demand for imports by home country $\mathrm{H}$

$\mathrm{P}_{\mathrm{ROW}}=$ ROW price

$\mathrm{P}_{\text {ROW }}^{\mathrm{t}}=$ ROW price inclusive of tariff $(\mathrm{t})$

$\mathrm{P}_{\mathrm{EU}}=\mathrm{EU}$ price

$\mathrm{S}_{\mathrm{EU}}=\mathrm{EU}$ export supply to $\mathrm{H}$

$\mathrm{S}_{\mathrm{ROW}}=$ ROW export supply to $\mathrm{H}$

$\mathrm{S}_{\text {ROW }}^{\mathrm{t}}=$ ROW export supply to Hwith tariff ( $\mathrm{t}$ )

The frameworkis adapted from Milner et al. (2005) and Zgovu and Kweka (2007). A small price taking country is initially importing from three sets of suppliers: neighbouring country/regional group of countries with Preferential Trade Agreement (PTA), the European Union (EU) and the Rest of the World (ROW). Both the EU and ROW initially face import tariffs while the PTA member(s) export with no tariffs into the home country $(\mathrm{H})$. Markets are assumed to be perfectly competitive and imports from the PTA, EU and SACU are treated as perfect substitutes of each other. The partial equilibrium analysis is used. The partner country $(\mathrm{P})$ is supplying the home country at increasing cost and hence, an upward sloping supply curve $S_{p}$ is noted. In Fig. 4, it is assumed that $\mathrm{P}_{\mathrm{EU}}>\mathrm{P}_{\mathrm{ROW}}$. Preferential trade agreement policies within the regional block (SACU in this case) can have both trade creating and trade diverting effects.

The initial supply by EU and ROW is assumed to be infinitely elastic; hence the horizontal supply curves $\mathrm{S}_{\mathrm{EU}}$ and $\mathrm{S}_{\mathrm{ROW}}$ respectively. Initially there is a discriminatory ad valorem tariff (t) on PTA nonmembers such that $\mathrm{P}_{\text {ROW }}^{\mathrm{t}}=\mathrm{P}_{\text {ROW }}(1+\mathrm{t})$ and $\mathrm{P}_{\mathrm{EU}}^{\mathrm{t}}=\mathrm{P}_{\mathrm{EU}}$ $(1+t), P_{E U}^{t}$ is not included for simplicity but would be above $\mathrm{P}_{\text {ROW }}^{\mathrm{t}}$ since $\mathrm{P}_{\mathrm{EU}}>\mathrm{P}_{\text {ROw. }}$. The relevant supply with tariffs imposed on extra regional imports is $\mathrm{S}_{\text {ROw }}^{\mathrm{t}}$. Country $\mathrm{H}$ imports $\mathrm{OM}_{1}$ from PTA member states, $M_{1} M_{2}$ from the ROW. The total imports are therefore $\mathrm{OM}_{2}$. Welfare (W) can thus be defined by import demand function of home country $\left(\mathrm{D}_{\mathrm{H}}\right)$, ruling out domestic production and supply capabilities. The welfare is the consumers' surplus and is given by triangle $\mathrm{ABP}_{\text {ROw }}^{\mathrm{t}}$ and the tariff revenue collected from ROW imports is estimated by area $(a+b)$. As a result of an Economic Partnership Agreement (EPA), the EU imports are no longer charged the discriminatory tariff $(\mathrm{t})$, which is still charged on extra-regional imports (ROW). EU imports are now duty free. From Fig. 4 the new supply price is $\mathrm{P}_{\mathrm{EU}}$ and accordingly, the supply curve is $\mathrm{S}_{\mathrm{EU}}$. Due to removal of tariffs on EU imports, total imports increase from $\mathrm{OM}_{2}$ to $\mathrm{OM}_{3}$. All imports are then coming from EU producers. 


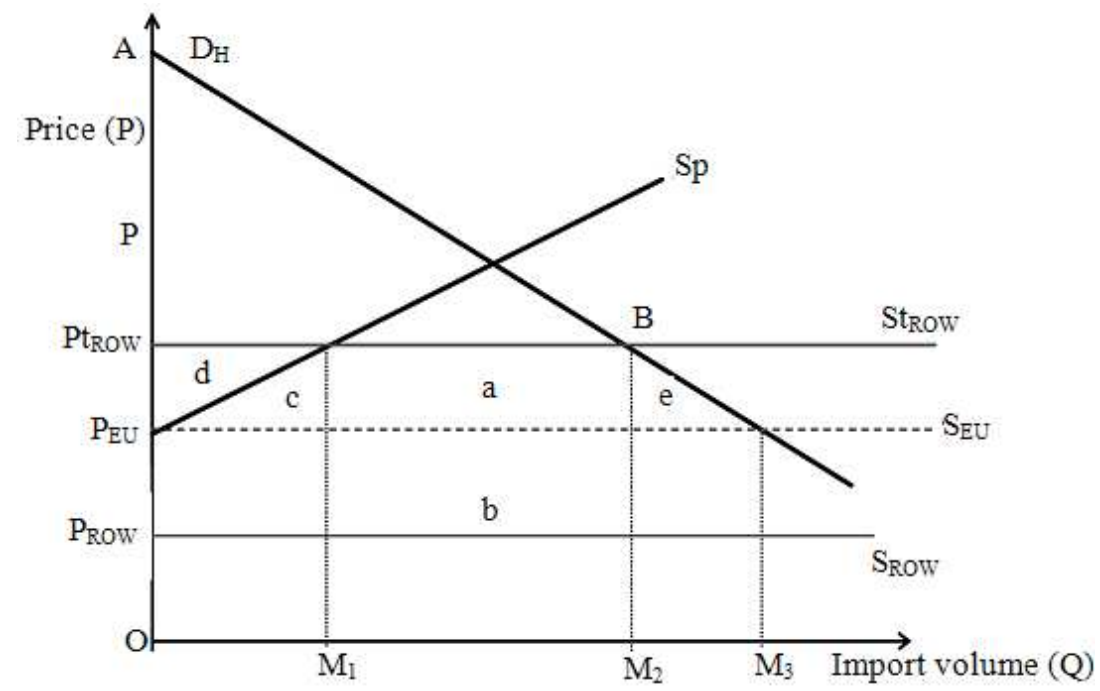

Fig. 1. Effect of a reciprocal SACU-EU EPA on imports (Milner et al., 2005)

The EPA has resulted in consumption expansion effect $\left(\mathrm{M}_{2} \mathrm{M}_{3}\right)$, trade diversion effect $\left(\mathrm{M}_{1} \mathrm{M}_{2}\right)$ and trade creation effect $\left(\mathrm{OM}_{1}\right)$. Trade diversion takes place whenever there is a shift in product origin from a nonmember producer whose resource costs are lower to a member producer whose resource costs are higher (Appleyard et al., 2006). In the case of an EPA, trade is diverted from relatively more efficient extra-regional suppliers; M1M2 is now imported from a less efficient EU compared to a relatively more efficient ROW. The resource cost is equal to area $b$, total tariff revenue lost by home country is area $(a+b)$. This is the potential maximum revenue that can be collected. Trade creation is said to occur when economic integration leads to a shift in product origin from domestic producer to a more resource cost efficient member (Appleyard et al., 2006). Similarly in the case of EPA, relatively less efficient intra-regional imports are being replaced by more efficient EU imports. The effect of trade creation is shown by area c. There is also producer surplus loss for partner countries equal to area $\mathrm{d}$. Trade diversion, trade creation and loss in producer surplus for partner countries increase consumer surplus by area $(a+d)$. This therefore, leaves the results of moving from a PTA to an EPA ambiguous because consumption and trade creation increases welfare, whereas trade diversion is welfare decreasing. Change in welfare is $\Delta \mathrm{W}=(\mathrm{c}+\mathrm{d}+\mathrm{e})-\mathrm{b}$. Area $\mathrm{e}$ is pure consumption effect of free trade between EU and country H. For any imports, the smaller the costs of trade-diversion then the greater the probability of a welfare improving EPA.

\subsection{Models and Data Analysis}

Imports source substitution elasticities were not available for specific goods andcountries. One high level of imports source substitution elasticity and a sensitivityanalysis were used to overcome this shortfall. Milner et al. (2005) argued this as an acceptable assumption as the data is disaggregated data. High elasticities of import source substitution are also justified by theaggregations of the EU and ROW, which are sufficiently large enough tomake the assumption of high substitutability between these alternative sources ofsupply reasonable. Milner et al. (2005) further stipulated that due to thediverse production structures of ROW and EU, it was reasonable to assume high import source substitution elasticity for a region's imports. The relativelyhigh level of disaggregation and the importance of import source substitution effects to the overall effects may be unlikely to bias theaggregate results (Milner et al., 2005). A sensitivity analysis wasconducted in this research to determine the effects of lower or higher imports source substitution elasticity.

Milner et al. (2005) stated that such an analytical framework should be treated as the aggregate picture for a homogenous single sector economy, where all the three trade effects (consumption, trade diversion and trade creation) due to a move from a PTA to an EPA occur simultaneously. The import source substitution, tariff 
revenue loss and welfare effects brought about by the EPA are estimated using the formulae outlined below:

- $\mathrm{t}^{\mathrm{EU}}=\mathrm{MFN}$ tariff rate imposed on extra regional imports including EU in the present time

- $\quad \mathrm{e}^{\mathrm{D}}{ }_{\mathrm{M}}=$ elasticity of demand for imports

- $\quad \mathrm{M}^{\mathrm{i}}=$ value of imports from $\mathrm{i}(\mathrm{i}=\mathrm{PTA}, \mathrm{EU}$ and ROW)

- $\sigma^{\mathrm{EU}}{ }_{\mathrm{k}}=$ elasticity of substitution between EU and $\mathrm{k}(\mathrm{k}$ $=$ PTA, ROW), $0 \leq \sigma_{\mathrm{k}}^{\mathrm{EU}} \leq 1$

\subsection{Consumption Effect}

$\Delta \mathrm{M}_{\mathrm{C}}=\left[\frac{-\mathrm{t}^{\mathrm{EU}}}{1+\mathrm{t}^{\mathrm{EU}}}\right] \cdot \mathrm{e}_{\mathrm{M}}^{\mathrm{D}} \cdot \mathrm{M}^{\mathrm{EU}}$

Consumption effect can be measured by using the elasticity of import demand function and the currently applied MFN ad valorem import tariffs charged by the home country on extra regional imports (Equation 1); and it is assumed that changes in prices of imports are caused by the change/removal of these tariffs. This value will be positive to reflect its welfare-enhancing nature.

\subsection{Trade Creation Effect}

$\Delta \mathrm{M}^{\mathrm{PTA}}=\left[\frac{\mathrm{t}^{\mathrm{EU}}}{1+\mathrm{t}^{\mathrm{EU}}}\right] \cdot \sigma_{\mathrm{SACU}}^{\mathrm{EU}} \cdot \mathrm{M}^{\mathrm{PTA}}$

Equation 2 can be used to measure trade creation caused by a switch of import source from PTA members to EU due to trade liberalisation between home country and EU, the elasticity of substitution is used between imports from the EU and those from the PTA. This value will be positive to reflect its welfare-enhancing nature.

\subsection{Trade Diversion Effect}

$\Delta \mathrm{M}^{\mathrm{ROW}}=\left[\frac{-\mathrm{t}^{\mathrm{EU}}}{1+\mathrm{t}^{\mathrm{EU}}}\right] \cdot \sigma_{\mathrm{ROW}}^{\mathrm{EU}} \cdot \mathrm{M}^{\mathrm{ROW}}$

The trade diversion Equation (3) captures the welfare decreasing effect of a switch of import source from relatively more efficient ROW to relatively less efficient EU suppliers. This value will be negative to reflect its welfare-lowering nature.

\subsection{Tariff Revenue Effect}

$$
\Delta \mathrm{R}=\mathrm{t}^{\mathrm{EU}}\left(-\mathrm{M}^{\mathrm{EU}}+\Delta \mathrm{M}^{\mathrm{ROW}}\right)
$$

Equation 4 shows the total tariff revenue effect given as the sum of the tariff loss on existing EU imports and the tariff lost due to a switch of import supplier from ROW to EU due to removal of tariffs on EU imports (due to trade diversion).

\subsection{Welfare Effects Due to Consumption Effect}

$\mathrm{W}_{\mathrm{C}}=\mathrm{t} \times\left(1 / 2 \Delta \mathrm{M}_{\mathrm{C}}\right)$

Equation 5 shows the welfare-raising effects of consumption because of cheaper duty-free prices on EU imports.

\subsection{Welfare Effects Due to Trade Creation}

$\mathrm{W}_{\mathrm{TC}}=\mathrm{t} \cdot\left(\Delta \mathrm{M}^{\mathrm{PTA}}\right)$

Equation 6 captures the welfare-raising nature of consumption due to trade creation.

\subsection{Welfare Effects Due to Trade Diversion}

$\mathrm{W}_{\mathrm{TD}}=-\mathrm{t}^{\mathrm{EU}} \times\left(\Delta \mathrm{M}^{\mathrm{ROW}}\right)$

Equation 7 captures the welfare reducing effects of trade diversion from least cost producers (ROW) to preference receiving EU producers.

\subsection{Overall Welfare Effect}

$\Delta \mathrm{W}=\mathrm{t}^{\mathrm{EU}}\left(1 / 2 \cdot \Delta \mathrm{M}_{\mathrm{C}}+\Delta \mathrm{M}^{\mathrm{PTA}}+\Delta \mathrm{M}^{\mathrm{ROW}}\right)$

A sum of all welfare effects from consumption and imports source substitution effects due to the removal of import tariffs on EU producers gives the overall welfare effect of the reciprocal EPA (Equation 8).

The trade data for this modeling were collected from the Botswana Central Statistics Office (CSO), also available at CSO website. Average trade weighted tariffs rateswere extracted from the United Nations Conference on Trade and Development' sdatabase via the World Bank's WITS/SMART. Country-specific average importdemand elasticities used were adapted from Kee et al. (2008) for allcommodities except for HS Code 13 and 14 (vegetables not specified elsewhere) that were taken from Vollmer et al. (2009). 


\section{RESULTS}

\subsection{Trade Impact and Changes in EU Exports into Botswana}

Total EU imports of food, beverages and tobacco into Botswana rise by an estimated BWP 294.11 million (BWP = Botswana Pula i.e., Botswana's national currency. Average BWP to US\$ was US\$1: BWP 6.95 for 2008 www.oanda.com/currency/historicalrates/); this is the sum of the increase in consumption, trade creation and trade diversion. The consumption effects account was for BWP 1.53 million, while the trade creation and trade diversion were BWP 281.25 millionand BWP 11.33 million respectively (Fig. 2).

EU imports into Botswana increases by $796 \%$ from the initial EU imports of BWP 36.95 million. This high increase is dueto trade creation as relatively inefficient SACU imports are substituted by efficient EU imports and some of the trade is diverted from tariff paying ROW totariff non-paying EU. When the elasticity of import substitution is decreased from 0.75 to 0.5 , EU imports rises by $532 \%$. With an import substitution elasticity valueof 1.0, EU imports increase by $1060 \%$. The higher percentage of trade creation shows the trade inhibitioneffect of SACU's import tariff duty on EU producers. This is because with a tariffduty on EU imports into Botswana, only $1 \%$ of food, beverages andtobacco is imported from EU, 3\% from ROW and a substantial 95\% isfrom within SACU states. When SACU and EU members are both not charged anytariff rates, then trade creation alone will account for $95.62 \%$ of the increasein EU imports.

\subsection{Tariff Revenue Effect}

The EPA's will result in tariff revenue losses through two primary means: (i) tariffrevenue forfeited due to EU imports not being levied duties; and (ii) initial duty paying ROW imports being substituted by duty non-paying EU imports. It is assumed thatsince no duty is initially paid on SACU imports there will be no tariff revenue lostwhen tariff non-paying SACU imports are replaced by tariff non-paying EU importsunder the SACU-EU EPA's. The total tariff revenue loss is BWP 3.676 million. BWP 1.41 million $(38 \%)$ is loss of tariff revenue due to not charging duty on current EUimports while BWP 2.26 million $(62 \%)$ is due to substituting ROW goods withtariff non-paying EU imports. Increases in EU imports due to consumption effectsbear no effect on tariff revenue because those imports will not exist if the tariff ratesare not eliminated.

\subsection{Net Welfare Impacts}

Welfare effects will come from increased consumption, trade creation and tradediversion. Figure 3 shows the welfare impacts of a SACU-EU EPA on Botswana's imports of food, beverages and tobacco. The net welfare isestimated to improve by BWP 54. 52 million. This is due to cheaper or more accessible EU imports of BWP 50,636 m. There is also an estimated welfare enhancement of BWP 56.73 $\mathrm{m}$ fromtrade creation. However, the welfare is estimated to decrease by BWP $2.26 \mathrm{~m}$ due totrade diversion. The results suggest a net welfare increase of $0.06 \%$ of the $2008 \mathrm{GDP}$ at 2008 prices.

\subsection{Consumption Effect}

Consumption effects measure the total value of new or additional imports as a resultof a duty and quota free SACU-EU EPA (Fig. 4). The results show anestimated additional import value of BWP 1.53 million. Of all the 24 two-digit HS codes analysed, the consumption effects isdominated by only six codes. These are dairy produce (HS Code 04), products of milling industries (HS Code 11), Cocoa (HS Code 18), preparations of cereals and milk (HS Code 19), miscellaneous edible preparations (HS Code 21) and beverages (HS Code $22)$. They account for $1.95,13.35,2.93,5.65,27.32$ and $47.84 \%$ respectively while all other goods take up just $0.01 \%$. Beverages have the highestincrease at BWP 733,785 . The results show a $0.52 \%$ consumption effect on overall increases in EU imports. The top four affected by new imports are HS codes 22, 21, 11 and 19. The least affected four are (excluding 01 and 02) (MFN ad valorem tariff of $2.8 \%$. There are initially no imports of 05 from the EU; given the formulae used, these two codes are not affected by the new SACU-EU duty free agreement) HS codes 06, 08, 10 and 16. The HS codes 22, 21 and 11 have aninitial above average ratio of EU imports compared to imports for each respective HS code, whereas the HS code 19 has large amount of imports and a relativelyhigher initial average trade weighted tariff of $21.9 \%$. The HS codes $06,08,10$ and 16 have an initial rather low or EU import, even thoughthese four codes have a relatively low average trade weighted tariffs and no EU imports. 
Buyani Thomy et al. / American Journal of Economics and Business Administration 5 (1): 1-14, 2013

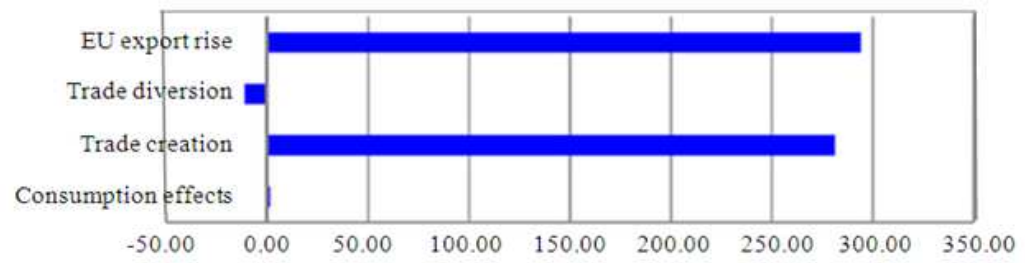

\begin{tabular}{|l|c|c|c|c|}
\cline { 2 - 5 } \multicolumn{1}{c|}{} & $\begin{array}{c}\text { Consumption } \\
\text { effects }\end{array}$ & Trade creation & Trade diversion & EU Export rise \\
\hline - Trade impacts & 1.53 & 281.25 & -11.33 & 294.12 \\
\hline
\end{tabular}

Fig. 2. Net trade impact of a SACU-EU EPA on Botswana imports and changes on imports from EU (2 Digit)-HS codes 01-24 using 2008 Data), BWP million

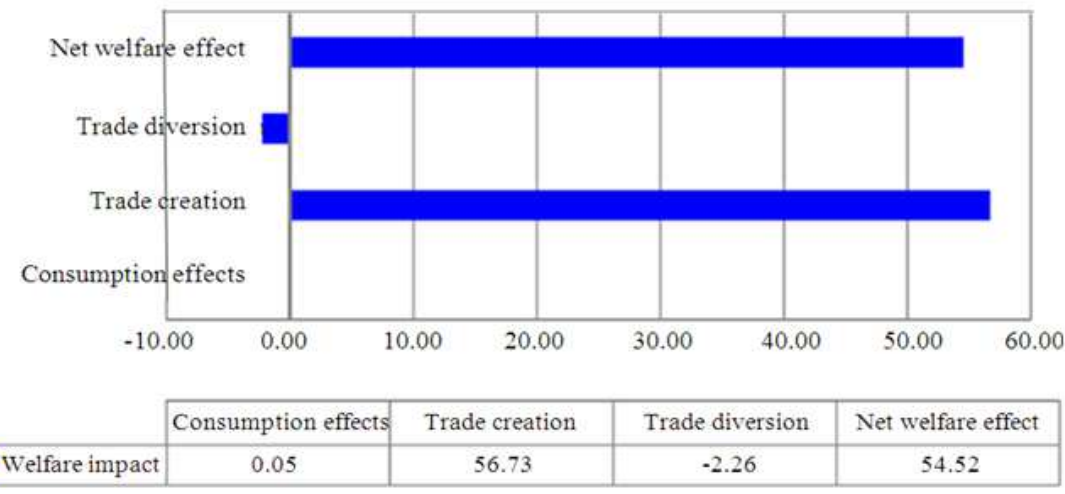

Fig. 3. Net welfare impacts of a SACU-EU EPA on imports of food, beverages and tobacco (in BWP million)

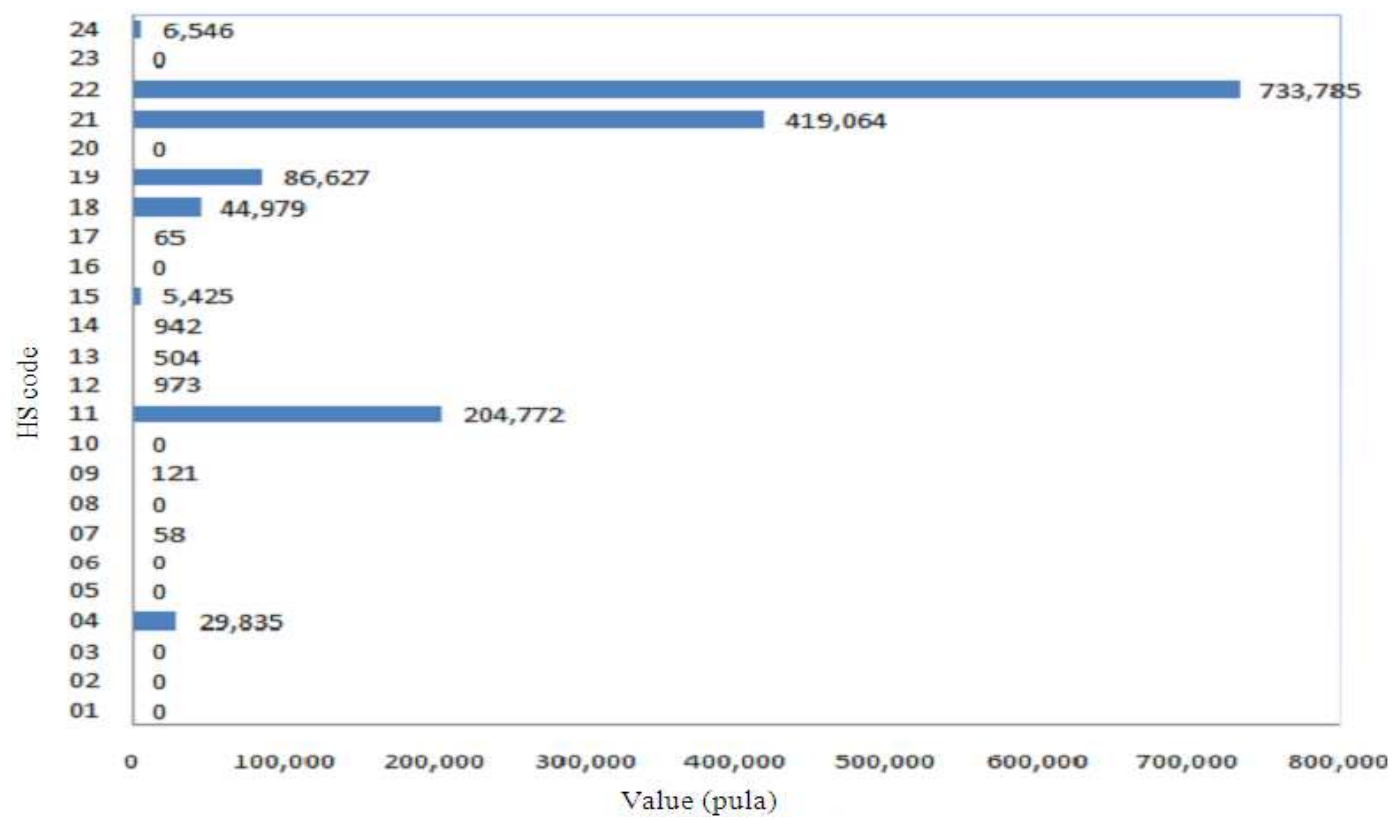

Fig. 4. Consumption effect (in BWP) 
This could be because of non-tariff trade barriers such astransport logistics and the availability of cheaper regionally produced goods. Thesefour codes cover flowers, nuts, cereals and fish preparations. In fact, Botswana can import these cheaplyfrom SACU (specifically South Africa and Namibia) or ROW than from EU.

\subsection{Trade Creation}

With trade creation (Fig. 5), HS code 24 (tobacco) has the highest estimated value at BWP $57.21 \mathrm{~m}$ (20.4\%). Other commodities with a higher trade creationthat will now be imported from relatively more efficient EU producersinstead of relatively less efficient SACU members are preparations of vegetables (HS Code 20) at $18.1 \%$, then preparations of cereals and milk (HS Code 19) at 9\%. Dairy produce (HS Code 04) also makes it into the top four with $8.6 \%$ of trade creation. These codes have a rather low ratio of EU imports to totalimports, tobacco, preparations of vegetables and fruits and preparations of cereals and milk also have high initial average trade weighted tariffs that later gives a high amount of trade creation. The HS codes non-edible vegetable products (14), gums, resinsand other vegetable saps (13), residues and other waste from food industries (23) and oilseeds and oleaginous fruits (12) all have low trade creation values; the codes 12,13 and 14 initially have lower amount of total imports and 23 has a low initial MFN averagetrade weighted tariff of $0.19 \%$. Elimination of tariffs between Botswana and EU does have a significant effect on EU imports and these imports substitute SACU imports.

\subsection{Trade Diversion}

An estimated BWP 11.33 million worth of trade is diverted from Relatively Efficient ROW producers to relatively inefficient EU producers who are not receivingpreferential treatment (Fig. 6). Trade is mostlydiverted in the following codes, vegetables, edible roots and tubes (07), tobacco (24), coffee, tea and spices (09) and sugar (17); these codes have relatively high amounts oftotal imports but low ratio of EU import to total imports. These four codes alsopossess an initial relatively high average trade weighted MFN tariffs; and their elasticity of demand for imports below 1.00. This means their demand isrelatively more elastic than that of most codes. Least affected codes in tradediversion are non-edible vegetable products (14), live trees and other plants (06), residues and other waste from food industries (23) and resins and other vegetable saps (13). These four codes initially have lower amount of total imports except for HS code 23, which experiences a smaller drop in tariff from 0.195 to $0.0 \%$. Edible vegetables, certain roots and tubers (HS Code 07) are the most affected with BWP3.39million diverted from ROW to EU suppliers.

\subsection{Tariff Revenue Effect}

Figure 7 shows a detailed total tariff revenue loss for each HS code. Tobacco (HS codes 24), beverages (22), miscellaneous edible preparations (21), preparations of cereals and milk (19), coffee, tea and spices (09) and vegetables, edible roots and tubers (07) are the most affected contributing $82 \%$ of the loss in revenue. These codes cover tobacco, beverages, cereals, coffee, tea, spices and vegetables and encompass staple dishes for an average Motswana (Motswana singular for a Botswana citizen). Tobacco and tobacco substitutes are the most affected group with a loss of BWP756, 973.

\subsection{Welfare Effect}

The top four codes that experience the highest welfare gain are tobacco (24), preparations of vegetables and fruits (20), preparations of cereals and milk (19) andcoffee, tea and spices (09) (Fig. 8). These codes have high initial average weightedtariff $(>20 \%)$. When tariffs are eliminated theirconsumer surplus increases sharply. They also have some of the highest importvalues. The lowest four gainers are non-edible vegetable products (14), gums, resins and other vegetable saps (13), residues and waste from the food industries (23) and cereals (10); these codes have low initial average weighted tariffs, low import values or both.

\subsection{Sensitivity Analysis}

A sensitivity analysis was carried out to investigate the effects of a change in the elasticity of import source substitution on different variables (Table 2). Elasticity of import source substitutions can be defined as the unit change in amount of goods imported from a foreign country given a unit change in tariff rates.

The results in Table 2 show that when a smaller elasticity of import source substitution of 0.5 is used:

- Trade creation decreases from BWP $281.25 \mathrm{~m}$ to BWP $187.5 \mathrm{~m}$

- Trade diversion decreases from BWP $11.33 \mathrm{~m}$ to BWP $7.55 \mathrm{~m}$

- Increases in EU imports by Botswana drops from BWP 294.12 million to BWP $196.59 \mathrm{~m}$

- Tariff revenue losses decrease from BWP 3.68 million to BWP $2.92 \mathrm{~m}$

- $\quad$ Net welfare effects also diminish from BWP 54.52 million to BWP $36.36 \mathrm{~m}$ 
Buyani Thomy et al. / American Journal of Economics and Business Administration 5 (1): 1-14, 2013

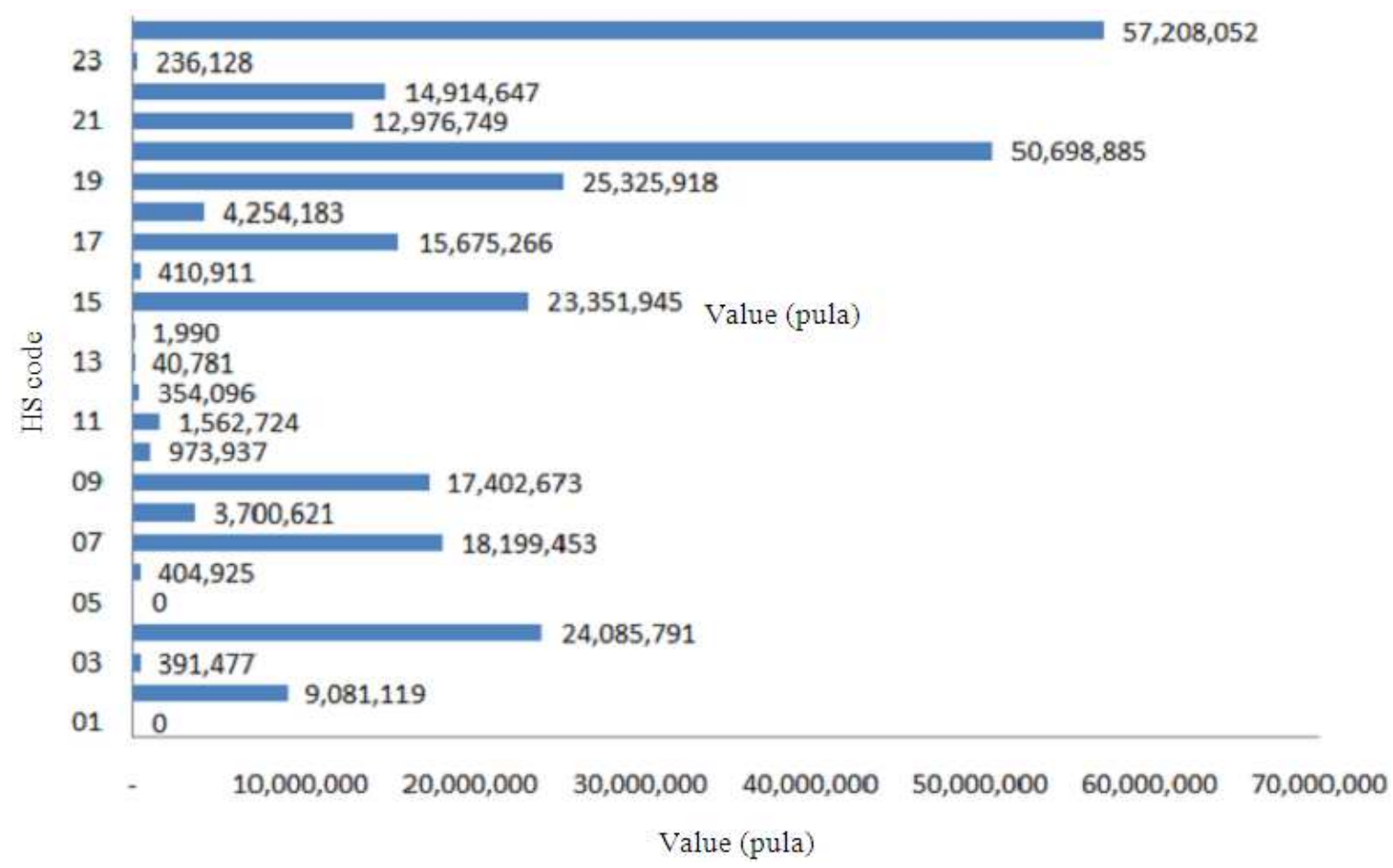

Fig. 5. Trade creation effect (in BWP)

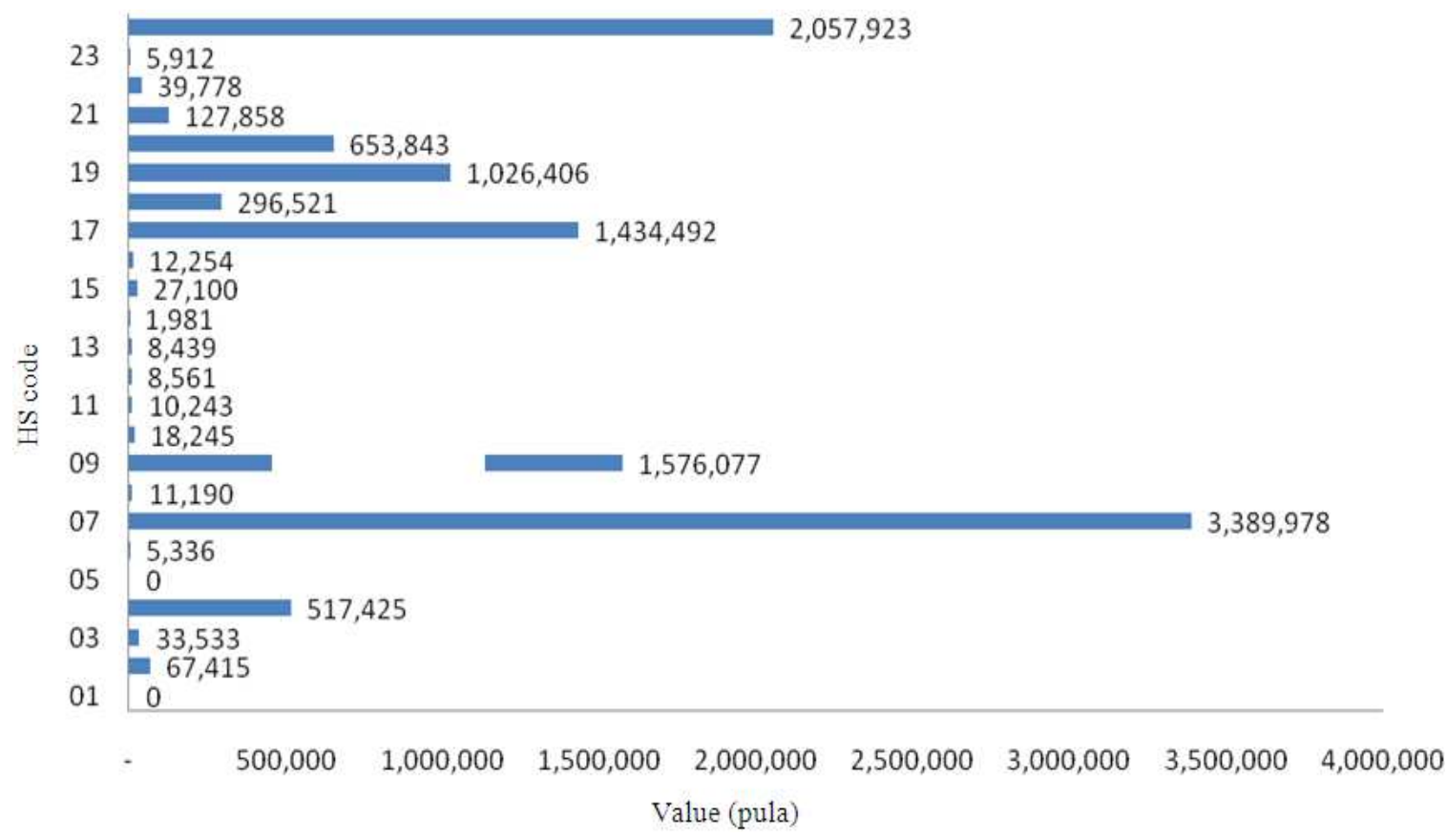

Fig. 6. Trade diversion effect (in BWP) 
Buyani Thomy et al. / American Journal of Economics and Business Administration 5 (1): 1-14, 2013

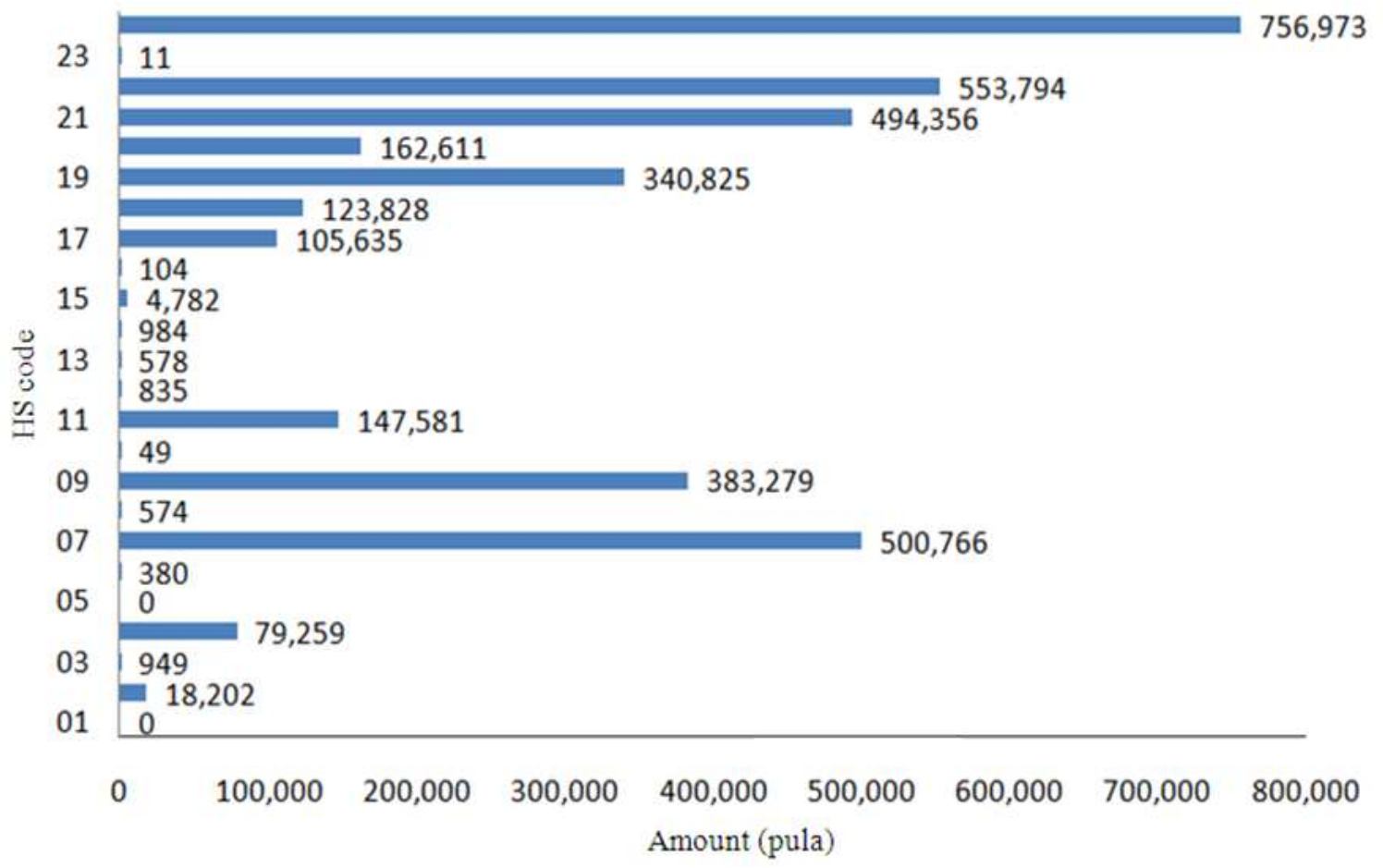

Fig. 7. Net tariff revenue effect (in BWP)

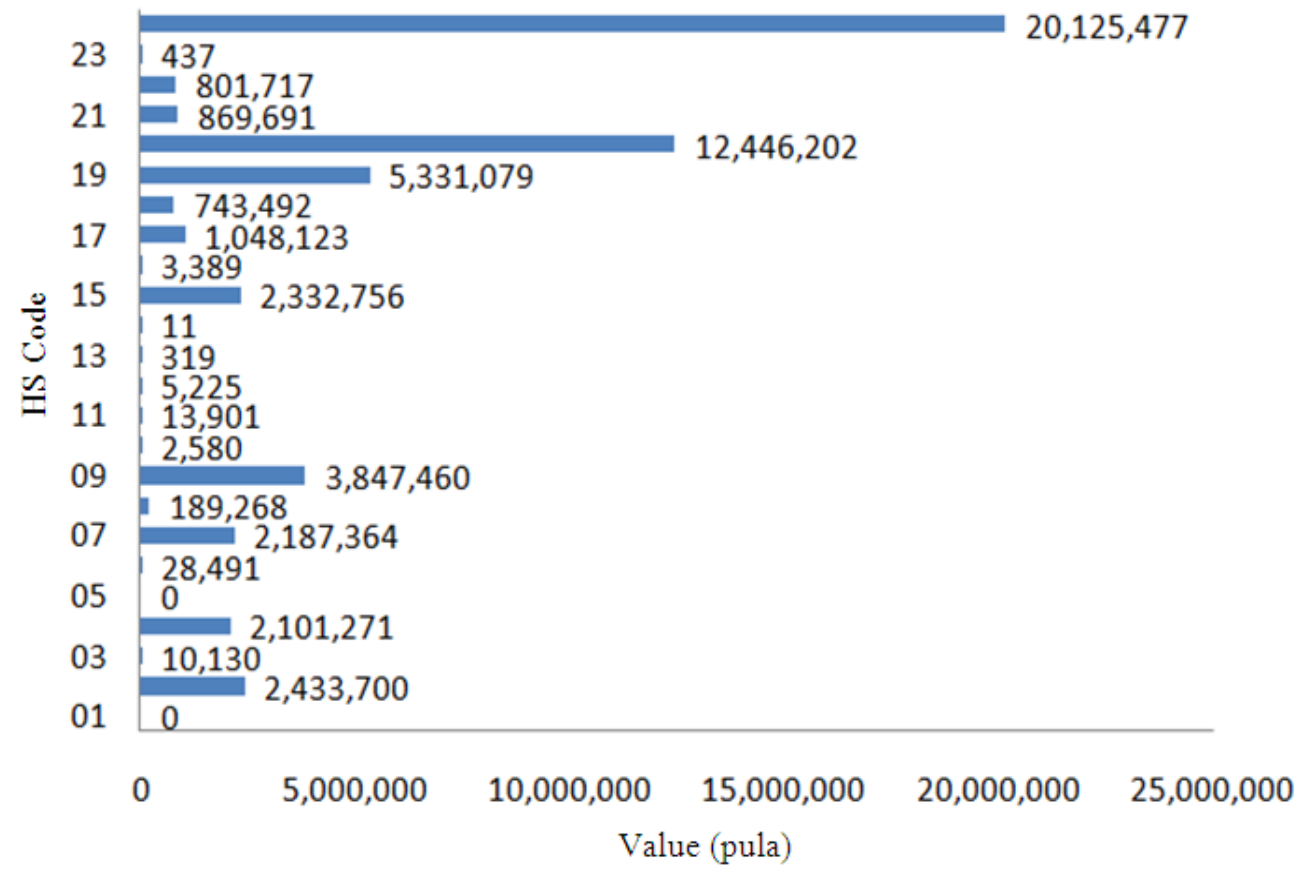

Fig. 8. Commodity level welfare effect in BWP 
Buyani Thomy et al. / American Journal of Economics and Business Administration 5 (1): 1-14, 2013

Table 2. Sensitivity analysis for import source substitution elasticity $(\sigma)$, values in millions of pula or percentage

\begin{tabular}{lrrr}
\hline$\sigma=$ & 0.5 & 0.75 & 1 \\
\hline 1. Consumption effects (additional imports) & 1.53 & 1.53 & 1.53 \\
2. Trade creation & 187.50 & 281.25 & 375.00 \\
3. Trade diversion & -7.55 & -11.33 & -15.11 \\
4. Overall increase in EU imports & 196.59 & 294.12 & 391.64 \\
5. Total tariff revenue effect & -2.92 & -3.68 & -4.43 \\
6. Net welfare effect & 36.36 & 54.52 & 72.68 \\
\hline
\end{tabular}

Currency in BWP million

NB $\sigma=$ elasticity of import source substitution

Source: Authors calculations

When a higher elasticity of import source substitution of 1.0 is used:

- Trade creation increases from BWP $281.25 \mathrm{~m}$ to BWP $375 \mathrm{~m}$

- Trade diversion rises from BWP $11.33 \mathrm{~m}$ to BWP $15.11 \mathrm{~m}$

- Increases in EU imports by Botswana rises from BWP 294.12 million to BWP 391.64 million

- Tariff revenue losses increase from BWP3.68million to BWP 4.43 million

- $\quad$ Net welfare effects also increase from BWP 54.52 million to BWP 72.68 million

A $25 \%$ change in elasticity of 0.75 results in a $33 \%$ change in the overall increase in EU imports as well as trade creation and diversion. The net welfare effects follow the same pattern whereas tariff revenue loss is less responsive: $20 \%$ change for a $25 \%$ change in elasticity of import source substitution. The consumption effects are not affected by the elasticity changes and thus remain constant at $\mathrm{P} 1.53$ million.

\section{DISCUSSION}

The sensitivity analysis on import source substitutability suggests that whether there is complete substitutability, or if the imports from the different regions are less substitutable, the net welfare effect remains positive. However, this net welfare increase is dependent on SACU signing the economic partnership with its European counterparts as a bloc, i.e., SACU has to remain intact and cooperate while the final agreement is signed and implemented. It has become evident that other members are either not in a hurry or are too wary of exposing their markets to more advanced EU producers and manufacturers with technology and skills capacity to produce more, at cheaper costs than the domestic SACU producers. This is perceived as a threat to the already small and struggling domestic producers. Namibia did not to sign the interim EPA's was because like South Africa, it expected the interim EPA to contain the changes agreed on by Baroness Ashton in Namibia. However, when the EU tabled the interim EPA's they lacked those provisions (Grynberg and Sekolokwane, 2009). Such problems are perceived to be the EU's attempts to protect itself from Asian competition. Some believe that EU's interest is not strictly in the development and regional integration of SACU or SADC (Grynberg and Sekolokwane, 2009).

The foreign exchange rates and currency stability against major trading partners will also have an effect on the benefits accrued by Botswana from a SACU-EU EPA. The benefits are indirectly reliant on sustained diamond revenue sales-one of the main contributors to Botswana's revenue. Should the Pula (BWP) depreciate greatly due to drops in diamond sales, specifically against the Euro $(€)$ or the Pound $(£)$, then the EU imports may be out-of-reach for Botswana. This may erode the benefits of a duty and quota free trade agreement but boost the export sector.

Southern African Development Committee (SADC) aspires to pursue the economic partnership agreement with EU as SADC rather than as SACU. All SACU members are concurrently members of the SADC. This is not likely to affect the results in any significant mannerbecause Botswana's sources imports are mostly from SACU (95\%) and there is no major trade from within SADC except from South Africa, a SACU member. Botswana is likely to continue importing from South Africa but will also import from the EU countries under the SACU-EU EPA's. Other SADC countries are more likely to compete with South Africa rather than with the sophisticated EU producers. Grynberg and Sekolokwane (2009) argued that the signing of the EPA's 
as SADC and not as SACU is unlikely due to many issues in the establishment and completion of a SADC customs union. For example, SADC must resolve the issues of double membership. Swaziland is concurrently a member of COMESA and in total seven of the thirteen SADC members are members of COMESA. Others such as Tanzania are doubling up SADC membership with that of the East African Customs Union.

The trade liberalization should give Botswana better access to cheap goods from alternative sources. The SACU-EU EPA's will be beneficial in improving Batswana's welfare by liberalising the import of food, beverages and tobacco. It is advisable for Botswana to complete these negotiations, along with Lesotho and Swaziland by signing the interim EPA's. While it is also important to negotiate favourable conditions, much time can be lost contending about absolute favourable agreements. It seems that some countries will benefit more than others and thus those who gain more than others may compensate others to help in establishing a fair trade scheme for the longer term.

In modern economy, the tariffs rates may not be the only hindrance to international trade. Environmental concerns, social objectives, public health, sustainability of crops/animals production and other non-economic objectives, non-tariff barriers appear to work against goods from developing countries (Mold, 2005). The SACU-EU EPA's will address the tariff barriers but the non-tariff barriers such as Sanitary and Phytosanitary (SPS) measures and non-automatic licensing also need to be scrutinized to make certain the trade is liberalised between SACU states and their counterpart EU states and that there is indeed a free-flow of goods amongst all concerned.

\section{CONCLUSION}

Import data from the Botswana Central Statistics Office was used to empirically quantify the effects of a SACU-EU EPA. The analysis assumed full trade liberalisation such that imports from the European Union enter Botswana duty and quota free just like goods from within the SACU bloc. From the calculations undertaken it has been concluded that, the implementation of a SACU-EU economic partnership agreement will be beneficial to Botswana. AVinerian approach partial equilibrium model was used to quantify the effects of the change in trade regime for Botswana's imports of food, beverages and tobacco (HS Codes 01 to 24). Trade effects, tariff revenue and welfare effect changes were estimated. Imports from European
Union producers into Botswana were estimated to increase to BWP 294.12 million, because of tradecreation, trade diversion and new imports (consumption effects). There is an estimatedtariff revenue loss of BWP 3.676 million but an estimated net welfareincrease of BWP $54.52 \mathrm{~m}$ due to duty free and quota free imports of food,beverages and tobacco.

More specifically, given that Botswana is a net importer of food, beverages and tobacco, trade liberalization should give Botswana better access to cheap goods from alternative sources. It seems that SACU-EU EPA's will be beneficial by liberalising the import of food, beverages and tobacco.Sensitivity analysis suggests that whether there is complete substitutability, or if the imports from the different regions are less substitutable, the net welfare effect remains positive. This net welfare increase is however dependent on SACU signing the economic partnership with its European counterparts as a united group.

Further given that diamonds arethe main industry, foreign exchange rates and currency stability against trading partners may negatively affect the benefits accrued from the SACU-EU EPA. A change in rates may erode the benefits but on the other had the agreement will tend to improve the export sector.

Clearly, tariffs rates are not the only hindrance for there are other reasons why international trade may not be totally fair, such as restrictions placed on some goods produced in the less developed countries. As such, it is important that in the end the trade is indeed liberalised and there is a free-flow of goods amongst countries.

It was noted that some countries in the group place the blame the EU for the agreement not being completed. The may be a perception thatthe EU may be attempting to protect itself from Asian competition rather than being seriously interested in the development and regional integration of SACU or SADC.

\subsection{Limitations}

Data was lacking at times for example the elasticities of import demand were not available from the World Bank for HS Codes13 and 14. However, elasticities calculated by Vollmer et al. (2009) were used intead. These elasticities were averages of one-digit HS Code 1 to which the two codesbelong. Also, the analysis methoddid not allow quantification or indeed the study the effectson local production capabilities and other related downstream industries. The Vinerian approach model did not capture the effects of non-tariffbarriers that are just as important as tariffs barriers to 
trade.Finally, this studyonly analysed the effects on imports of agricultural and related goods, ignoring the manufacturing and services sectors.

\section{REFERENCES}

Akinkugbe, O., G.R. Motlaleng and P. Makepe, 2006. Botswana and the Multilateral Trading System: The Impact of WTO Agreements, Negotiations and Implementation. 1st Edn., New York, Geneva, pp: 51.

Appleyard, D.R., A.J. Field and S.L. Cobb, 2006. International Economics. 5th Edn., McGraw Hill, Boston, ISBN-10: 0072877375, pp: 784.

Flatters, F. and M. Stern, 2005. Implementing the SACU Revenue-Sharing Formula: Customs Revenue.

Grynberg, R. and K. Sekolokwane, 2009. Signing of the Interim Economic Partnership Agreement. BIDPA, Gaborone.

Kee, H.L., A. Nicita and M. Olarreaga, 2008. Import demand elasticities and trade distortions. Rev. Econ. Stat., 90: 666-682. DOI: 10.1162/rest.90.4.666

Lehloenya, P.M., 2009. The Failed SACU-USA Free Trade Agreement in Hindsight: A Lost Opportunity or Disaster Averted? J. inter. Commercial Law Techonol., 4: 117-127.

Meyn, M., 2004a. The TDCA and the Proposed SACUUSA FTA: Are Free Trade Agreements with Industrialised Countries Beneficial for SACU? 1st Edn., Namibian Economic Policy Research Unit, Windhoek, pp: 44.
Meyn, M., 2004b. Are Economic Partnership Agreements likely to Promote or Constrain Regional Integration in Southern Africa? 1st Edn., Ausspannplatz, pp: 19.

Milner, C., O. Morrissey and A. Mckay, 2005. Some simple analytics of the trade and welfare effects of economic partnership agreements. J. Afr. Econ., 14: 327-358. DOI: 10.1093/jae/eji006

Mold, A., 2005. Non-Tariff Barriers: Their Prevalence and Relevance for African Countries. African Trade Policy Centre andrew Mold, pp: 38.

Sawkut, R. and S. Boopen, 2010. An assessment of the impact of a COMESA Customs Union. Afr. Dev. Rev., 22: 331-345. DOI: 10.1111/j.14678268.2010.00241.x

Sigwele, H.K., 2007. The effects of international trade liberalization on food security and competitiveness in the agricultural sector of Botswana. PhD Thesis.

Vollmer, S., I. Martinez-Zarzosoy, D.F. NowakLehmann and N.H. Klan, 2009. EU-ACP Economic Partnership Agreements: Empirical Evidence for Sub-Saharan Africa. Washington, DC: World Bank.

Zgovu, E.K. and J.P. Kweka, 2007. Empirical Analysis of Tariff-line level Trade, Tariff Revenue and Welfare Effects of reciprocity under EPAs with the EU: Evidence from Malawi and Tanzania. United Nations. Economic Commission for Africa; African Development Bank Group. 